\title{
ON BOUNDARY DOMINATION IN THE JENSEN-MERCER INEQUALITY
}

\author{
IVAN PERIĆ
}

Abstract. The main purpose of this, mainly expository, paper is to give various arguments that the boundary domination is a crucial property for the Jensen-Mercer inequality. Although this is an obvious property of convex functions and it is already expressed in the Jensen inequality it seems that the Jensen-Mercer inequality contains this information in a more vivid, explicit sense. This domination is presented using Steffensen-Popoviciu measures, The Majorization Theorem and a crude domination of weights of vertices in the multidimensional case (polytopes, simplices).

Mathematics subject classification (2010): 26A51, 26D15.

Keywords and phrases: Jensen-Mercer inequality, Jensen inequality, Steffensen-Popoviciu measures, Majorization Theorem, functionals, polytopes.

\section{REFERENCES}

[1] S. Abramovich, M. Klaričić Bakula, M. Matić, J. PeČArić, A variant of Jensen-Steffensen's inequality and quasi-arithmetic means, J. Math. Anal. Appl. 307 (2005), 370-386.

[2] J. BARIĆ, A. MAtKović, Bounds for the normalized Jensen-Mercer functional, J. Math. Inequal. 3, 4 (2009), 529-541.

[3] W. S. Cheung, A. Matković, J. PeČArić, A variant of Jessen's inequality and generalized means, J. Inequal. Pure and Appl. Math. 7, 1 (2006), Article 93.

[4] I. GAVREA, Some considerations on the monotonicity property of power means, J. Inequal. Pure and Appl. Math. 5, 4 (2004), Article 93.

[5] A. GuESSAB, Direct and converse results for generalized multivariate Jensen-type inequalities, J. Nonlinear Convex Anal. 13 (2012), 777-797.

[6] A. Guess AB, O. NouisSER, J. PeČARIĆ, A multivariate extension of an inequality of Brenner-Alzer, Arch. Math. (Basel) 98, 3 (2012), 277-287.

[7] S. IVELIĆ, J. PEČARIĆ, Generalizations of converse Jensen's inequality and related results, J. Math. Inequal. 5, 1 (2011), 43-60.

[8] A. R. Khan, M. Praljak, J. PeČArić, Note on generalized Mercer's inequality, Bull. Malays. Math. Sci. Soc., to appear

[9] M. Kian, M. S. Moslehian, Refinements of the operator Jensen-Mercer inequality, Electron. J. Linear Algebra 26 (2013), 742-753.

[10] M. Klaričić Bakula, Z. Pales, J. PeČarić, On weighted L-conjugate means, Commun. Appl. Anal. 11, 1 (2007), 95-110.

[11] Anita Matković, The Jensen-Mercer Inequality, PhD thesis, University of Zagreb, 2006.

[12] A. MatKović, J. PeČARIć, A variant of Jensen's inequality in a Hilbert space, Toyama Math. J. 28 (2005), 93-103.

[13] A. MATKOVIĆ, J. PEČARIĆ, A variant of Jensen's inequality for convex functions of several variables, J. Math. Inequal. 1, 1 (2007), 45-51.

[14] A. Matković, J. PeČARIĆ, I. PERIĆ, A variant of Jensen's inequality of Mercer's type for operators with applications, Linear Algebra Appl. 418, 2-3 (2006), 551-564.

[15] A. MAtKović, J. PeČARIĆ, J. Perić, A refinement of the Jessen-Mercer inequality and a generalizations on convex hulls in $\mathbb{R}^{k}$, manuscript.

[16] A. McD. Mercer, A variant of Jensen's inequality, J. Inequal. Pure and Appl. Math. 4, 4 (2003), Article 73 
[17] D. S. Mitrinović, J. E. PeČARIĆ, Classical and new inequalities in analysis, Mathematics and its Applications, East European Series 61, Kluwer Academic Publishers Group, 1993.

[18] F.-C. Mitroi, C. I. SPIRIdon, Refinements of Hermite-Hadamard inequality on simplices, Math. Rep. (Bucur.) 15 (65)(1) (2013), 69-78.

[19] C. P. Niculescu, L.-E. Persson, Convex Functions and Their Applications: A Contemporary Approach, Springer, 2006.

[20] C. P. Niculescu, On a result of G. Bennett, Bull. math. Soc. Sci. Math. Roumanie (N. S.) 54, 3 (102) (2011), 261-267.

[21] M. NiezGodA, A generalization of Mercer's result on convex functions, Nonlinear Anal: Theory Methods Appl. 71 (2009), 2771-2779.

[22] Z. PAVIĆ, J. PEČARIĆ, I. PERIĆ, Integral, discrete and functional variants of Jensen's inequality, J. Math. Inequal 5, 2 (2011), 253-264.

[23] J. PEČARIĆ, J. PERIĆ, Generalizations and improvements of converse Jensen's inequality for convex hulls in $\mathbb{R}^{k}$, Math. Inequal. Appl. 17, 3 (2014), 1125-1137.

[24] J. E. PeČarić, F. Proschan, Y. L. Tong, Convex Functions, Partial Orderings and Statistical Applications, Academic Press, Inc., 1992.

[25] O. E. Tikhonov, A note on definition of matrix convex functions, Linear Algebra Appl. 416 (2006), 773-775.

[26] S. Wasowicz, A. Witkows Ki, On some inequality of Hermite-Hadamard type, Opuscula Math. 4, 3 (2012), 591-600. 